ISSN 1392-3196 / e-ISSN 2335-8947

Zemdirbyste-Agriculture, vol. 103, No. 1 (2016), p. 91-98

DOI 10.13080/z-a.2016.103.012

\title{
Determination of tomato quality attributes using near infrared spectroscopy and reference analysis
}

\author{
Audrius RADZEVIČIUS, Jonas VIŠKELIS, Rasa KARKLELIENĖ, \\ Danguole JUŠKEVIČIENĖ, Pranas VIŠKELIS \\ Institute of Horticulture, Lithuanian Research Centre for Agriculture and Forestry \\ Kauno 30, Babtai, Kaunas distr., Lithuania \\ E-mail: a.radzevicius@1sdi.lt
}

\begin{abstract}
The research objective was determination of ripening attributes of intact tomato (Lycopersicon esculentum Mill.) cv. 'Rutuliai' using near infrared (NIR) spectroscopy and reference analysis. Tomatoes were picked at six different ripening stages in order to evaluate the correlation between data obtained by near infrared spectra and physicalchemical analyses and how the quality parameters change during ripening. Primarily, spectroscopic measurements were followed by chemical analyses. NIR spectroscopy measurements and reference analyses showed that tomato fruit had lost skin and flesh firmness during the ripening processes and there were no big differences between the methods used for the determination of dry matter and soluble solids ( ${ }^{\circ}$ Brix) and the obtained results varied slightly. The obtained results of dry matter, soluble solids content $\left({ }^{\circ} \mathrm{Brix}\right)$ and fruit skin and flesh firmness were presented as simple linear regression between NIR spectroscopy and reference analyses. A high correlation between NIR spectroscopy and reference analyses of dry matter was established and this correlation, expressed by regression coefficient, reached 0.9089. Regression coefficient between NIR spectroscopy and reference analyses of soluble solids was 0.815. Meanwhile, the highest correlation was detected for tomato fruit skin and flesh firmness and regression coefficient, respectively, reached 0.9119 and 0.9624 . Hence the near infrared calibration has the potential to estimate the physical-chemical properties of tomato fruit according to their infrared spectra.
\end{abstract}

Key words: ${ }^{\circ}$ Brix, dry matter, firmness, maturity, near infrared.

\section{Introduction}

Tomato (Lycopersicon esculentum Mill.) is one of the most popular vegetables in the world. Tomato fruit consists of water and soluble and insoluble solids. Soluble solids are traditionally expressed as degrees Brix ( ${ }^{\circ}$ Brix) and mainly consist of sugars (sucrose and fructose) and salts (Salunkhe, Kadam, 1995; Beckles, 2011). Insoluble solids (4-8\%) are mainly constituted of Salunkhe and Kadam (1995); therefore, tomato solids are very valuable at the factory processing. Higher amount of tomato solids need less amount of fruits to produce the same amount of tomato products (Beckles, 2011; Siddiqui, 2015). Total dry matter content in different tomato cultivars varies from $4 \%$ to $7.5 \%$ of fruit fresh mass. Soluble solids account for $75 \%$ of the total solids and are comprised primarily of the reducing sugars, which represent $55-65 \%$ of the total soluble solids content. Most of these organic compounds absorb near infrared (NIR) radiation due to the presence of functional groups (e.g., R-OH, R-NH $, \mathrm{R}-\mathrm{CH}, \mathrm{R}-\mathrm{CH}_{2}$ and $\mathrm{R}-\mathrm{CH}_{3}$ ) on the molecules. So, this makes it possible to develop an analytical technique based on NIR absorption spectrometry to determine soluble solids content of tomatoes non-destructively (Peiris et al., 1998).
Since its introduction in the early 1970's, the use of NIR spectroscopy has progressed rapidly in a number of fields. Its rapid adoption owes much to its distinct advantages: quick response time, simplicity of sample preparation, chemical free measurements and simultaneous measurement of multiple attributes. Food chemistry has greatly benefited from these developments, which allow the determination of a series of properties, such as soluble solid content, acidity and dry matter in different food matrixes (Chen et al., 2008; Zhu et al., 2015).

Consumersevaluatetomatofruitqualityaccording to colour and firmness, probably these parameters are the most important attributes that determine overall fruit quality. Tomato maturity is traditionally classified into six ripening stages according to the colour change of the fruit from green to red (USDA Color Chart, 2011). Colour evolution during fruit ripening is mainly related to the breakdown of chlorophyll and synthesis of lycopene, which is responsible for the red colour and constitutes $75-83 \%$ of the total pigment content at full ripeness (Clement et al., 2008; Radzevičius et al., 2014; Schouten 
et al., 2014). During fruit ripening, cell wall hydrolytic enzymes contribute to tissue softening and lessening of intercellular adhesion and tomatoes lose their firmness (Brummel, 2006; Toivonen, Brummell, 2008). However, the ability of fruit flesh to resist compressive force is one of the most important characteristics to estimate fruit maturity and quality. Generally, firmness may be evaluated by touch or by penetrometer measurement. Both of these two methods are destructive and firmness value can vary greatly depending on the method used and the competence of an executor. Recently, measurement of the optical properties of fruits has been one of the most successful non-destructive techniques for quality assessment. Optical techniques, NIR spectroscopy for instance, have received considerable interest as a means for non-destructive evaluation of fruit firmness (Kusumiyati et al., 2008; Tiwari et al., 2013). Nevertheless, total soluble solids, dry matter and fruit firmness are very important internal quality attributes of vegetables (Karklelienè et al., 2014; Siddiqui, 2015). Most instrumental techniques to measure these properties are destructive and involve a considerable amount of manual work and money. So, researches have presently been focused on developing non-destructive techniques, e.g., visible/NIR spectroscopy, for measuring internal fruit quality attributes (Berra, 2012; Radzevičius et al., 2014).

NIR spectroscopy technique has gained a great deal of attention in food quality analysis mainly due to its suitability for recording the spectra of solid and liquid samples at lowest cost and without any pretreatment. The main characteristics hindering NIR spectra expansion are broad, weak, non-specific, extensively overlapped bands. After multivariate calibration methods became widely available and accepted, NIR spectroscopy technique has been widely studied and applied (Chen et al., 2008; Tiwari et al., 2013; Deak et al., 2015). However, the potential use of visible NIR spectroscopy for tomato and tomato based products has been evaluated only by several researchers (Kusumiyati et al., 2008; Berra, 2012; Tiwari et al., 2013; Deak et al., 2015).

However, many researchers have proposed non-destructive methods for measuring internal quality of fruits and vegetables at fully ripen stage. For better explanation and accuracy, characteristics of NIR spectroscopy should be evaluated during all fruit ripening period, from green tomato ripening stage to fully ripen stage, because tomato fruit colour, flavour and texture change during ripening period.

The research objective was to determine ripening attributes (dry matter, ${ }^{\circ}$ Brix, skin and flesh firmness) during tomato fruit ripening of intact tomato (Lycopersicon esculentum Mill.) cv. 'Rutuliai' using near infrared (NIR) spectroscopy and reference analyses and compare accuracy of the methods used.

\section{Materials and methods}

Investigation was carried out at the Institute of Horticulture, Lithuanian Research Centre for Agriculture and Forestry in 2012-2013. Tomato cv. 'Rutuliai' was grown in the natural soil in a non-heated greenhouse, according to the tomato growing technology adopted by Institute of Horticulture (Jankauskienè, Survilienè, 2003). In the first year (2012) of experiment, samples (total number of samples reached 96) were used as calibration set and obtained data processed using software Sacmi NCS Vers. 3.0 RC 1 (NIR calibration software). In the second year (2013), evaluation and comparisons of near infrared spectroscopy characteristics and reference analyses were made.

In order to evaluate the correlation between NIR spectra and physical-chemical analyses and the change of quality parameters during ripening, tomatoes were picked at six different ripening stages: 1 - ripeness stage means $100 \%$ green tomato fruit, 2 - ripeness stage means a definite "break" in colour from green to red (up to $10 \%$ coloured tomato fruit), 3 - ripeness stage shows a definite change in colour from green to red (10-30\% coloured tomato fruit), 4 - ripeness stage shows $30-60 \%$ coloured tomato fruit, 5 - ripeness stage means that tomato fruit gained colour specific to nature (60-90\% coloured tomato fruit) and 6 - ripeness stage, fully ripen tomato (over $90 \%$ coloured tomato fruit) (USDA Color Chart, 2011). Therefore, tomatoes were selected based on their colour uniformity (from 1 till 6 stages of ripeness). Each fruit was individually numbered. As the fruits were harvested from different plants, the experiment design was completely randomized with each fruit as an experimental unit.

The following fruit quality parameters at different ripening stages were evaluated: dry matter, soluble solids in fresh matter, fruit skin and flesh firmness. Tomato fruits at each ripening stage were harvested at random in four replications. Primarily, spectroscopic measurements using spectrophotometer NIR Case NCS001A (Sacmi Imola S. C., Italy) were made and afterwards physical-chemical analyses (texture measured using texture analyser, dry matter - gravimetrically, ${ }^{\circ}$ Brix - using digital refractometer) were performed. Four tomato fruits were measured at each ripening stage four times; therefore total number of samples was 96.

Spectroscopic measurements were performed using NIR spectrophotometer NIR Case NCS001A. Measurement range was $600-1000 \mathrm{~nm}$. The raw intensity spectrum of each fruit was taken around the tomato equator in four positions with approximately $90^{\circ}$ between them. All physical-chemical analyses were performed immediately after NIR measurements.

After acquiring NIR spectral data, skin and flesh firmness of the same tomato fruit were analysed. Tomato fruit texture was measured using a texture analyser TA.XTPlus (Stable Micro Systems, England). For each test, every single tomato was punctured on the specific positions around the equatorial area, with approximately $90^{\circ}$ between them and the perpendicular to the stembottom axis. The obtained data was processed using software Texture Exponent. The firmness was expressed as the peak force and recorded in N. After the firmness 
measurements, dry matter and soluble solids of each fruit were analysed. Dry matter content was determined gravimetrically by drying tomatoes to a constant weight at $105^{\circ} \mathrm{C}$. In order to determinate soluble solids, tomatoes were cut in small pieces immediately after firmness measurements and homogenized using a blender Bosch Easy Mixx, type CNHR6(RobertBosch GmbH, Germany) and measured by a digital refractometer ATAGO PR-32 (Atago Co. Ltd., Japan). Total soluble solids (sugars and salts) were expressed as $\%$ in fresh mass.

Data of each ripening stage was presented as an average of 16 measurements (16 measurements $=4$ tomato fruits $\times 4$ replications of each fruit). Significant differences were estimated by Fisher's least significant difference (LSD) test $(P \leq 0.05)$ and standard deviation (SD); also coefficient of variation $(\mathrm{CV})$ was calculated. Statistical software STATISTICA 7.0, MS Excel and $A N O V A$ were used for data calculation and significance evaluation.

\section{Results and discussion}

The data of our study showed that the amount of dry matter and soluble solids ( ${ }^{\circ}$ Brix) varied during fruit ripening and depended on the ripeness stage of tomato (Table, Figs. 1-2). The highest values of these parameters were established in fully ripened fruits $\left(6^{\text {th }}\right.$ ripeness stage), when predicted values of dry matter ranged from

Table. Dry matter, soluble solids, skin and flesh firmness of tomatoes at different ripeness stages measured using near infrared (NIR) spectroscopy and reference analyses

\begin{tabular}{|c|c|c|c|c|c|c|c|c|c|}
\hline \multirow{2}{*}{$\begin{array}{l}\text { Ripe- } \\
\text { ness } \\
\text { stage }\end{array}$} & \multirow{2}{*}{$\begin{array}{l}\text { Tomato } \\
\text { number }\end{array}$} & \multicolumn{2}{|c|}{$\begin{array}{c}\text { Dry matter } \\
\%\end{array}$} & \multicolumn{2}{|c|}{$\begin{array}{c}\text { Soluble solids ( }\left({ }^{\circ} \text { Brix }\right) \\
\%\end{array}$} & \multicolumn{2}{|c|}{$\begin{array}{l}\text { Skin firmness } \\
\mathrm{N} \mathrm{cm}^{-2}\end{array}$} & \multicolumn{2}{|c|}{$\begin{array}{c}\text { Flesh firmness } \\
\mathrm{N} \mathrm{cm}^{-2}\end{array}$} \\
\hline & & $\begin{array}{c}\text { NIR } \\
\text { measurements }\end{array}$ & $\begin{array}{l}\text { reference } \\
\text { analyses }\end{array}$ & $\begin{array}{c}\text { NIR } \\
\text { measurements }\end{array}$ & $\begin{array}{l}\text { reference } \\
\text { analyses }\end{array}$ & $\begin{array}{c}\text { NIR } \\
\text { measurements }\end{array}$ & $\begin{array}{l}\text { reference } \\
\text { analyses }\end{array}$ & $\begin{array}{c}\text { NIR } \\
\text { measurements }\end{array}$ & $\begin{array}{l}\text { reference } \\
\text { analyses }\end{array}$ \\
\hline \multirow{6}{*}{1} & 1 & 6.245 & 6.432 & 3.18 & 3.40 & 443.5 & 455.3 & 101.3 & 89.4 \\
\hline & 2 & 6.030 & 6.128 & 3.15 & 3.20 & 417.6 & 416.8 & 105.3 & 91.2 \\
\hline & 3 & 6.210 & 6.314 & 3.11 & 3.70 & 418.2 & 421.8 & 104.9 & 96.2 \\
\hline & 4 & 6.300 & 6.443 & 4.01 & 3.80 & 405.4 & 407.9 & 106.6 & 106.5 \\
\hline & $\mathrm{LSD}_{05}$ & 0.157 & 0.181 & 0.57 & 0.49 & 39.4 & 48.8 & 7.5 & 8.7 \\
\hline & $\mathrm{CV} \%$ & 1.886 & 2.309 & 12.837 & 7.812 & 4.738 & 7.615 & 2.159 & 8.034 \\
\hline \multirow{6}{*}{2} & 1 & 6.685 & 6.753 & 3.09 & 3.15 & 435.4 & 411.1 & 110.8 & 106.1 \\
\hline & 2 & 7.190 & 7.627 & 3.27 & 3.30 & 398.9 & 356.4 & 99.8 & 101.2 \\
\hline & 3 & 6.305 & 6.600 & 3.39 & 3.70 & 422.0 & 371.2 & 78.6 & 57.8 \\
\hline & 4 & 5.965 & 6.183 & 2.85 & 3.30 & 393.9 & 346.9 & 93.6 & 77.5 \\
\hline & $\mathrm{LSD}_{05}$ & 0.436 & 0.819 & 0.42 & 0.68 & 50.3 & 36.9 & 18.2 & 22.3 \\
\hline & $\mathrm{CV} \%$ & 8.044 & 8.943 & 7.494 & 7.014 & 3.799 & 4.867 & 14.061 & 26.164 \\
\hline \multirow{6}{*}{3} & 1 & 7.860 & 7.919 & 4.98 & 4.80 & 387.0 & 328.3 & 45.8 & 44.8 \\
\hline & 2 & 5.820 & 5.604 & 3.27 & 3.33 & 382.3 & 361.4 & 76.6 & 71.5 \\
\hline & 3 & 6.085 & 6.154 & 3.58 & 3.80 & 379.8 & 395.9 & 60.8 & 62.3 \\
\hline & 4 & 5.820 & 5.659 & 3.37 & 3.40 & 358.3 & 358.4 & 66.5 & 54.0 \\
\hline & $\mathrm{LSD}_{05}$ & 1.390 & 1.752 & 1.13 & 0.91 & 15.3 & 47.0 & 17.9 & 20.4 \\
\hline & $\mathrm{CV} \%$ & 15.381 & 17.136 & 20.904 & 17.676 & 3.379 & 7.661 & 20.628 & 19.630 \\
\hline \multirow{6}{*}{4} & 1 & 6.270 & 6.494 & 4.17 & 4.70 & 301.8 & 291.0 & 31.6 & 17.2 \\
\hline & 2 & 6.280 & 6.719 & 4.84 & 4.50 & 344.6 & 313.5 & 46.3 & 45.9 \\
\hline & 3 & 5.875 & 6.024 & 3.64 & 4.00 & 312.4 & 315.9 & 45.3 & 37.7 \\
\hline & 4 & 6.025 & 5.940 & 4.05 & 4.40 & 277.8 & 289.6 & 21.4 & 21.4 \\
\hline & $\mathrm{LSD}_{05}$ & 0.247 & 0.594 & 1.35 & 0.76 & 22.9 & 26.1 & 11.8 & 12.7 \\
\hline & $\mathrm{CV} \%$ & 3.230 & 5.938 & 11.972 & 6.691 & 8.963 & 4.668 & 32.865 & 44.262 \\
\hline \multirow{6}{*}{5} & 1 & 5.695 & 5.840 & 3.49 & 3.70 & 309.0 & 260.7 & 46.7 & 44.9 \\
\hline & 2 & 5.630 & 5.992 & 4.18 & 4.30 & 281.2 & 278.1 & 23.0 & 24.4 \\
\hline & 3 & 5.645 & 6.056 & 5.09 & 5.00 & 251.2 & 231.6 & 21.0 & 21.7 \\
\hline & 4 & 5.455 & 5.652 & 3.88 & 3.70 & 278.1 & 254.6 & 30.8 & 21.5 \\
\hline & $\mathrm{LSD}_{05}$ & 0.316 & 0.519 & 1.58 & 1.24 & 32.4 & 25.7 & 12.4 & 5.1 \\
\hline & $\mathrm{CV} \%$ & 1.866 & 3.057 & 16.361 & 14.814 & 8.435 & 7.507 & 38.411 & 39.992 \\
\hline \multirow{6}{*}{6} & 1 & 7.670 & 7.673 & 5.25 & 4.90 & 260.0 & 256.2 & 12.8 & 16.2 \\
\hline & 2 & 7.620 & 7.479 & 4.19 & 4.70 & 234.7 & 215.9 & 8.8 & 16.5 \\
\hline & 3 & 5.645 & 6.149 & 3.98 & 4.45 & 214.7 & 211.8 & 11.9 & 12.1 \\
\hline & 4 & 5.785 & 6.268 & 4.08 & 4.70 & 223.2 & 174.5 & 6.9 & 12.0 \\
\hline & $\mathrm{LSD}_{05}$ & 2.243 & 1.597 & 1.15 & 0.51 & 23.6 & 30.1 & 7.2 & 4.7 \\
\hline & CV\% & 16.706 & 11.532 & 13.516 & 3.931 & 8.440 & 15.557 & 27.019 & 17.438 \\
\hline
\end{tabular}

$\mathrm{CV} \%-$ coefficient of variation $=$ standard deviation $/$ average $\times 100$ 
$5.645 \%$ up to $7.670 \%$ (measured by NIR spectroscopy) and from $6.149 \%$ to $7.673 \%$ (measured by reference analyses). The highest amount of soluble solids in fully ripe tomatoes ranged from $3.98 \%$ to $5.25 \%$ (measured by NIR spectroscopy) and from $4.45 \%$ to $4.90 \%$ (measured by reference analyses). NIR spectroscopy measurements and reference analyses showed that tomato fruit had lost skin and flesh firmness during ripening processes. The data of our study agree with the data of other scientists. Batu (2004) reported that firmness values of two investigated tomato cultivars ('Liberto' and 'Criterium') decreased during ripening. Nour et al. (2014) stated that dry matter and soluble solids recorded a slight decrease during tomato growth, and the stage of ripening significantly influenced the content of all bioactive compounds. Nour et al. (2014) also admitted that the first stages of ripening were characterized by a slight decrease in the dry matter content, while this variation reversed in the last two stages of ripening.

The average data of dry matter measurements using NIR and reference methods are presented in Figure 1. The highest amount of dry matter was detected in fully ripe fruits and reached 6.680 according to NIR spectroscopy and $6.892 \%$ according to reference analyses, but NIR measurements showed the highest means of standard deviation (1.116) and coefficient of variation (16.706\%) (Table, Fig. 1). Meanwhile, according to reference analyses, the highest means of standard deviation (1.085) and coefficient of variation $(17.136 \%)$ of predicted values had been established in tomatoes at the $3^{\text {rd }}$ ripeness stage. Comparison of two different measurements during tomato ripening showed, that there were no significant differences between them, and obtained results varied slightly.

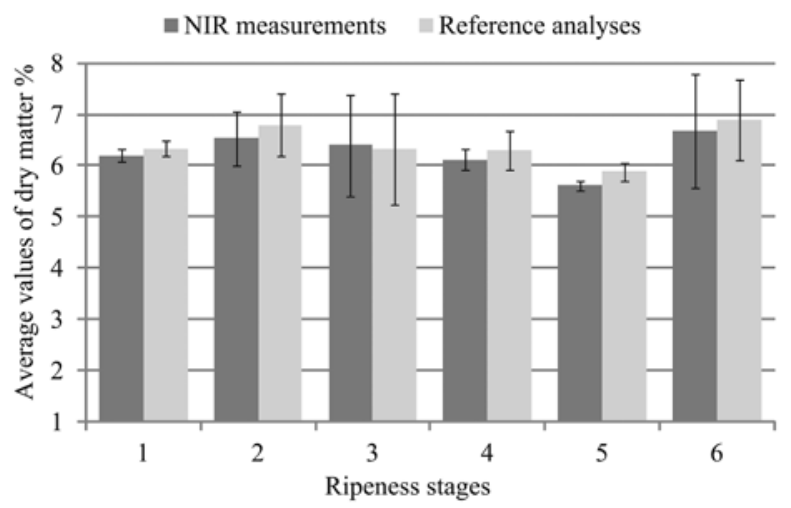

Note. Error bars show standard deviation (SD) value.

Figure 1. Amount of dry matter at different ripeness stages measured using near infrared (NIR) spectroscopy and reference analyses

Travers and colleagues (2014) predicted dry matter and soluble solids content in apples using NIR spectroscopy and obtained that $R^{2}$ values range between 0.63 and 0.86 with residual predictive deviations between 1.7 and 2.7. These values were not high enough for general quantitative predictions and certain factors affected success, including changes in fruit physiology over time.
Another study demonstrated that NIR spectroscopy is a suitable tool for quantification of dry matter in kiwifruit with small prediction errors over the entire range (Qiang et al., 2010).

Average data of soluble solids content determined by NIR spectroscopy and reference analyses during tomato ripening are presented in Figure 2. The data of our study showed that average means of soluble solids measured by NIR spectroscopy varied from 3.15\% ( $2^{\text {nd }}$ ripeness stage) up to $4.37 \%$ ( $6^{\text {th }}$ ripeness stage) and measured by reference analyses had varied from $3.36 \%$ ( $2^{\text {nd }}$ ripeness stage $)$ up to $4.69 \%\left(6^{\text {th }}\right.$ ripeness stage $)$.

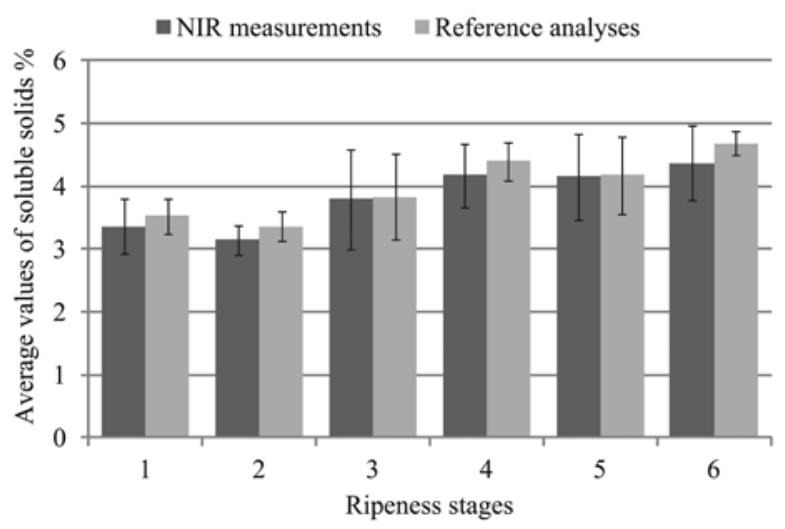

Note. Error bars show standard deviation (SD) value.

Figure 2. Amount of soluble solids $\left({ }^{\circ} \mathrm{Brix}\right)$ at different ripeness stages measured using near infrared (NIR) spectroscopy and reference analyses

There were no significant differences between the data obtained using NIR spectroscopy and reference analyses, even means at the $3^{\text {rd }}$ and $5^{\text {th }}$ tomato ripeness stages were identical. The highest means of standard deviation (Fig. 2), coefficient of variation (Table) and data variation emerged at the $3^{\text {rd }}$ ripeness stage using both detection methods. The lowest values of standard deviation (0.18) and coefficient of variation (3.931\%) were obtained using reference analyses in fully ripen fruits. Previous studies related to determination of tomato fruit quality using NIR spectroscopy technique revealed (He et al., 2005) that calibration correlation coefficient between the NIR measurements and reference analyses of soluble solids ( ${ }^{\circ}$ Brix) content was high as 0.95 , with the standard error of calibration 0.11 . When the model was used to predict the other samples, the prediction results were also tolerable, with the correlation coefficient between the measured and the predicted $(r)$ 0.90; the standard error of prediction was 0.19 (He et al., 2005). Equally, soluble solids were successfully predicted by VIS/NIR spectroscopic method in different fruits - apple, kiwi. In apples the highest correlation coefficient was 0.98 , depending on the number of principal components and the pre-processing techniques (Liu, Zhou, 2013). Qiang et al. (2010) used NIR spectroscopy for dry matter determination in kiwifruit and reported that it could be determined non-destructively and dry matter can be predicted with very good accuracy and high correlation 
coefficient $(r=0.902)$. Peiris and colleagues (1998) demonstrated that there is a relationship between soluble solids content in tomatoes and NIR absorbance that can be exploited to estimate soluble solids of individual intact tomatoes. Pedro and Ferreira (2007) reported that standard error of soluble solids prediction in tomato was 1.14 and was similar to standard error of reference methods, and were comparable with results previously reported for NIR measurements. The data of our study revealed that the amount of soluble solids, determined by NIR spectroscopy and reference analyses, varied slightly and there were no significant differences between the methods used.

Traditionally, fruit firmness was estimated in a destructive manner by means of the Magness Taylor test. This test may be performed in the laboratory or using portable equipment and is based on the introduction of a cylindrical head into the flesh of a peeled fruit to measure the maximum penetration force. The development of sensors to measure fruit firmness features is one of the challenges of post-harvest technology. Fruit packing companies need to measure quality variables, but they need to do so in a non-destructive manner. Manufacturers and researchers are currently developing sensors with this aim (Garcia-Ramos et al., 2005; Sirisomboon et al., 2012).

It was established that coefficient of variation varied in small range from $3.379 \%$ up to $8.963 \%$ (Table), standard deviation - from $12.7 \%$ up to $27.7 \%$ (Fig. 3) according to the data on tomato skin firmness obtained using the non-destructive method. Meanwhile, data obtained using reference analyses varied a little greater: SD - from $14.1 \%$ up to $33.4 \%$ and CV - from $4.668 \%$ up to $15.557 \%$.

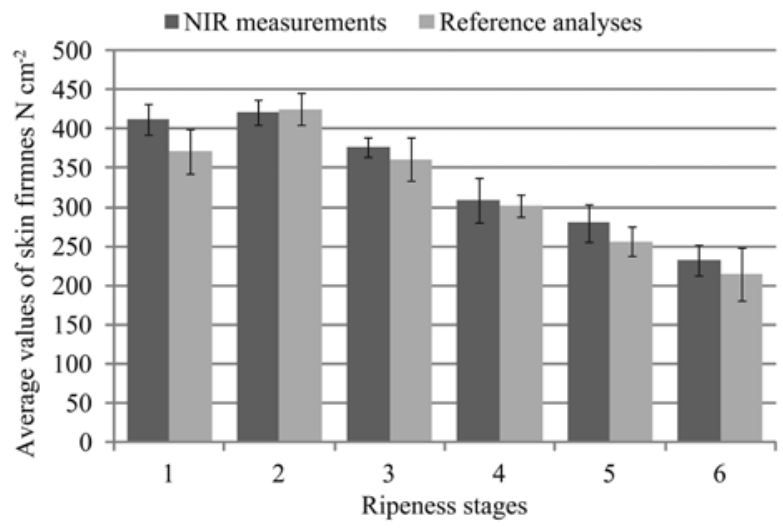

Note. Error bars show standard deviation (SD) value.

Figure 3. Tomato skin firmness at different ripeness stages measured using near infrared (NIR) spectroscopy and reference analyses

Comparison of tomato skin firmness determined using NIR spectroscopy and reference analyses revealed that detected values were similar and there were no significant differences between the methods used. This agrees with the data of other scientists. He with colleagues (2005) studied the use of NIR spectroscopy in measuring the quality characteristics of tomato cv. 'Heatwave' and established the relationship between NIR spectra and the major fruit physiological properties, including fruit firmness. The results showed excellent prediction performances with the standard error of prediction of compression force $(r=0.81)$ was $16.017 \mathrm{~N}$; and that of puncture force $(r=0.83)$ was $1.18 \mathrm{~N}$. Kusumiyati with co-workers (2008) investigated on-tree and after-harvest tomato firmness using portable NIR spectroscopy and established positive linear correlation. Results of our and other studies (He et al., 2005; Kusumiyati et al., 2008) of NIR measurements may contribute to the prediction of the optimal harvesting time of fruit on-tree when the desired levels of firmness and colour values are developed. On the other hand, the after-harvesting NIR measurement may be used as a fast and non-destructive technique for sorting or grading fruits based on desired quality attributes.

Various methods are used for efficient simplification and interpretation of many different variables simultaneously. The methods reveal the main structures and relationships in huge data tables, giving relatively simple output graphs and tables that have maximum information and minimal repetition and noise (Maindonald, Braun, 2010; Siddiqui, 2015). Simple linear regression is the most commonly used technique for determination of how one variable of interest (the response variable) responses to changes in another variable (the explanatory variable). The quantities that result from regression analyses may be written in many different forms that are mathematically equivalent but superficially distinct. Besides the regression variables, the third parameter of fundamental importance is the correlation coefficient $r$ or the coefficient of determination $R^{2}$, which shows the ratio between the variance (Maindonald, Braun, 2010).

It was established that fruit lost flesh firmness during ripening processes (Fig. 4). The lowest predicted values of flesh firmness were established in the $6^{\text {th }}$ ripeness stage and were $10.1 \mathrm{~N} \mathrm{~cm}^{-2}$ (measured by NIR spectroscopy) and $14.2 \mathrm{~N} \mathrm{~cm}^{-2}$ (measured by reference

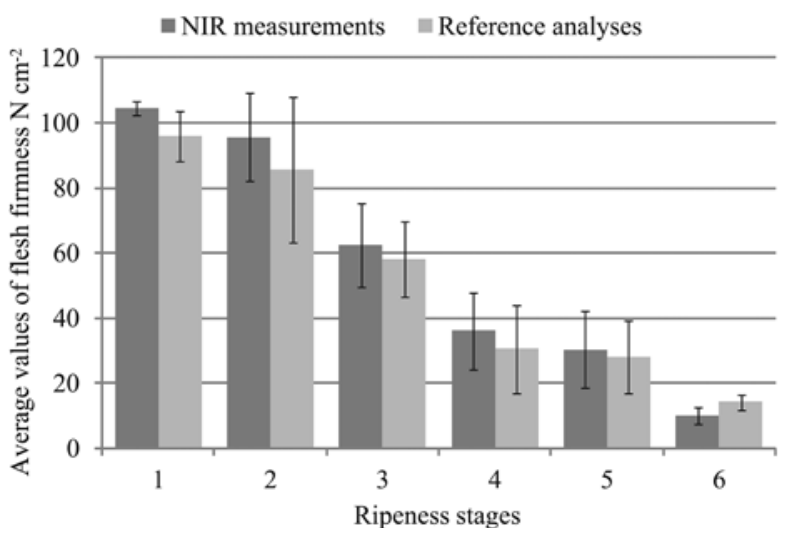

Note. Error bars show standard deviation (SD) value.

Figure 4. Tomato flesh firmness at different ripeness stages measured using near infrared (NIR) spectroscopy and reference analyses 
analyses). The strongest flesh firmness of tomato fruits detected in the $1^{\text {st }}$ ripeness stage was $104.5 \mathrm{~N} \mathrm{~cm}^{-2}$ (measured by NIR spectroscopy) and $95.8 \mathrm{~N} \mathrm{~cm}^{-2}$ (measured by reference analyses). Comparison of values of tomato flesh firmness determined by NIR spectroscopy and reference analyses revealed that detected means were similar and there were no significant differences between the methods used.

Prediction results of dry matter, soluble solids content and fruit skin and flesh firmness are presented in Figures 5-8. In all figures, the ordinate and abscissa axes respectively represent the actual (measured by reference analyses) and predicted (measured by NIR spectroscopy) values. The simple linear regression implied between them for each characteristic. The correlation between the NIR spectroscopy and reference analyses of dry matter was high and was expressed by regression coefficient, which was 0.9089 . Regression coefficient between NIR spectroscopy and reference analyses of soluble solids was 0.815 . Meanwhile, the highest correlation was established for tomato fruit skin (regression coefficient was 0.9119) and flesh (regression coefficient was 0.9624 ) firmness.

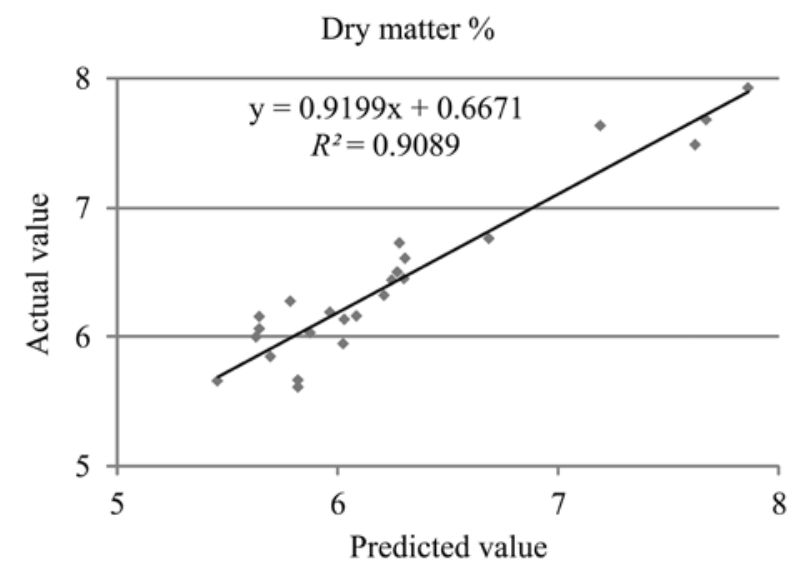

Figure 5. NIR prediction accuracy of dry matter

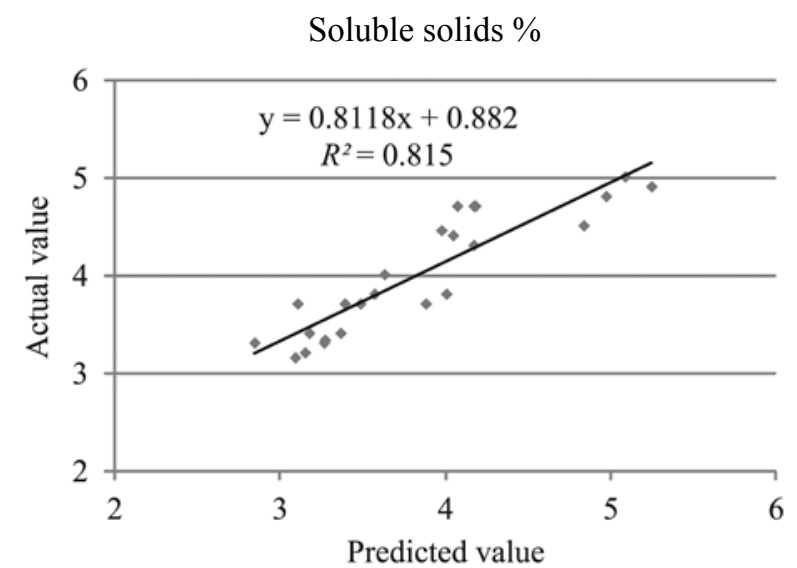

Figure 6. NIR prediction accuracy of soluble solids content ( ${ }^{\circ}$ Brix)

The advantages of NIR spectroscopy are obvious. It is a fast and non-destructive method for measuring the quality parameters; it provides a possibility to measure

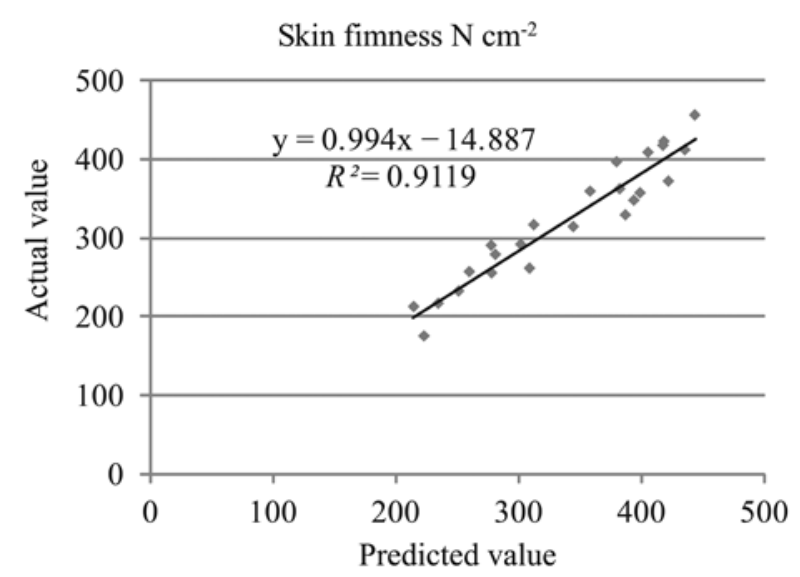

Figure 7. NIR prediction accuracy of tomato skin firmness

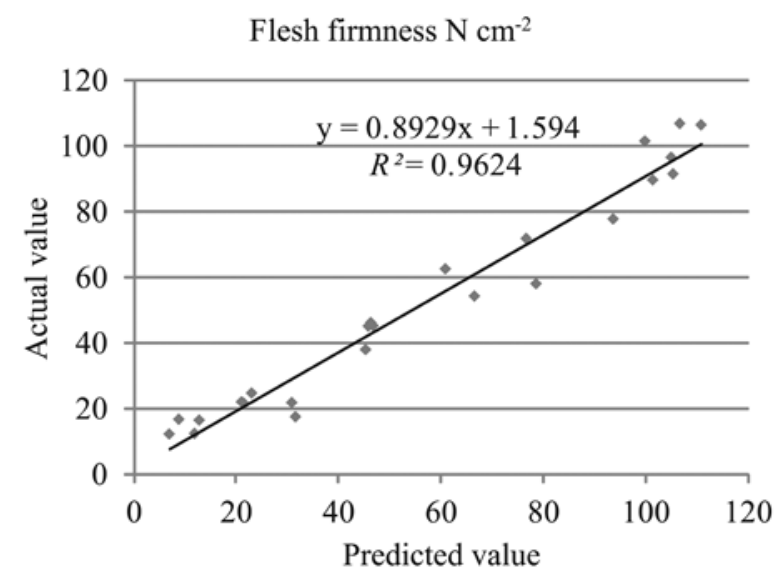

Figure 8. NIR prediction accuracy of tomato flesh firmness

the same sample as many times as needed. Our data show that it is possible to employ this non-destructive technique for evaluation of the quality characteristics of tomato. For better NIR prediction accuracy more experiments with tomatoes remains to be done. The NIR calibration has the potential to estimate the component concentrations of the chemical and physical properties in the tomatoes according to their infrared spectra.

\section{Conclusions}

1. The highest values of dry matter and soluble solids ( ${ }^{\circ}$ Brix) parameters were established in fully ripe tomato fruits $\left(6^{\text {th }}\right.$ ripeness stage $)$, when predicted values of dry matter ranged from $5.645 \%$ to $7.670 \%$ (measured by NIR spectroscopy) and from $6.149 \%$ to $7.673 \%$ (measured by reference analyses). The highest amount of soluble solids in fully ripened tomatoes ranged from $3.98 \%$ to $5.25 \%$ (measured by NIR spectroscopy) and from $4.45 \%$ to $4.90 \%$ (measured by reference analyses).

2. Comparison of near infrared (NIR) measurements and reference analyses for dry matter and soluble solids ( ${ }^{\circ}$ Brix) determination showed that obtained results varied slightly.

3. NIR spectroscopy measurements and reference analyses showed that tomato fruits lost skin and flesh firmness during ripening processes. 
4. The NIR calibration has the potential to estimate the physical-chemical properties of tomato fruits according to their infrared spectra.

\section{Acknowledgments}

Postdoctoral fellowship is being funded by European Union Structural Funds project "Postdoctoral Fellowship Implementation in Lithuania”.

Received 19062015

Accepted 13012016

\section{References}

Batu A. 2004. Determination of acceptable firmness and colour values of tomatoes. Journal of Food Engineering, 61: $471-475$ http://dx.doi.org/10.1016/S0260-8774(03)00141-9

Beckles D. M. 2011. Factors affecting the postharvest soluble solids and sugar content of tomato (Solanum lycopersicum L.) fruit. Postharvest Biology and Technology, 63 (1): 129-140

http://dx.doi.org/10.1016/j.postharvbio.2011.05.016

Berra W. G. 2012. Visible/near infrared spectroscopic method for the prediction of lycopene in tomato (Lycopesicon esculentum Mill.) fruits. Science, Technology and Arts Research Journal, 1 (3): 17-23 http://dx.doi.org/10.4314/star.v1i3.98795

Brummell D. A. 2006. Cell wall disassembly in ripening fruit. Functional Plant Biology, 33 (2): 103-119 http://dx.doi.org/10.1071/FP05234

Chen L., Raghavan G. S. V., Charlebois D., Charles M. T., Vigneault C. 2008. Non-destructive measurement of tomato quality using visible and near-infrared reflectancece spectroscopy. The Canadian Society for Bioengineering, 8 (197): 1-15

Clement A., Dorais M., Vernon M. 2008. Multivariate approach to the measurement of tomato maturity and gustatory attributes and their rapid assessment by Vis-NIR Spectroscopy. Journal of Agricultural and Food Chemistry, 56: $1538-1544$ http://dx.doi.org/10.1021/jf072182n

Deak K. J., Szigedi T., Palotas G., Daood H. G., Helyes L. 2015. Determination of ${ }^{\circ}$ Brix, lycopene, $\beta$-carotene and total carotenoid content of processing tomatoes using near infrared spectroscopy. Acta Horticulturae, 1081: 253-258 http://dx.doi.org/10.17660/ActaHortic.2015.1081.32

Garcia-Ramos F. J., Valero C., Homer I., Ortiz-Cannavate J., Ruiz-Altisent M. 2005. Non-destructive fruit firmness sensors: a review. Spanish Journal of Agricultural Research, 3 (1): 61-73

http://dx.doi.org/10.5424/sjar/2005031-125

He Y., Zhang Y., Pereira A. G., Gomez A. H., Wang J. 2005. Nondestructive determination of tomato fruit quality characteristics using Vis/NIR spectroscopy technique. International Journal of Information Technology, 11 (11): 97-108

Jankauskienė J., Survilienè E. 2003. Daržovių auginimas šiltnamyje. Lithuanian Institute of Horticulture, $80 \mathrm{p}$. (in Lithuanian)

Karklelienė R., Dambrauskienė E., Juškevičienė D., Radzevičius A., Rubinskienè M., Viškelis P. 2014. Productivity and nutritional value of dill and parsley. Horticultural Sciences, 41 (3): 131-137

Kusumiyati A., Akinga T., Tanaka M., Kawasaki S. 2008. On-tree and after-harvesting evaluation of firmness, color and lycopene content of tomato fruit using portable NIR spectroscopy. Journal of Food, Agriculture and Environment, 6 (2): 327-332
Liu Y., Zhou Y. 2013. Quantification of the soluble solids content of intact apples by vis-NIR transmittance spectroscopy and the LS-SVM method. Spectroscopy, 28: 1-7 http://dx.doi.org/10.1155/2013/453980

Maindonald J., Braun W. J. 2010. Data analysis and graphics using $R$ : an example-based approach ( $3^{\text {rd }}$ ed.). Cambridge, $\mathrm{UK}, 525 \mathrm{p}$.

Nour V., Trandafir I., Ionica M. 2014. Evolution of antioxidant activity and bioactive compounds in tomato (Lycopersicon esculentum Mill.) fruits during growth and ripening. Journal of Applied Botany and Food Quality, 87: 97-103

Pedro A. M. K., Ferreira M. M. C. 2007. Simultaneously calibrating solids, sugars and acidity of tomato products using PLS2 and NIR spectroscopy. Analytica Chimica Acta, 595: 221-227

http://dx.doi.org/10.1016/j.aca.2007.03.036

Peiris K. H. S., Dull G. G., Leffler R. G., Kays S. J. 1998. Near-infrared (NIR) spectrometric technique for nondestructive determination of soluble solids content in processing tomatoes. Journal of the American Society for Horticultural Science, 123 (6): 1089-1093

Qiang L., Mingjie T., Jianrong C., Huazhu L., Chaitep S. 2010. Selection of efficient wavelengths in NIR spectrum for determination of dry matter in kiwi fruit. Maejo International Journal of Science and Technology, 4 (01): 113-124

Radzevičius A., Viškelis P., Viškelis J., Karklelienė R., Juškevičienè D. 2014. Tomato fruit color changes during ripening on vine. International Journal of Agricultural, Biosystems Science and Engineering, 8 (2): 34-36

Salunkhe D. K., Kadam S. S. 1995. Handbook of fruit science and technology. New York, USA, $611 \mathrm{p}$

Schouten R. E., Farneti B., Tijskens L. M. M., Alarcon A. A., Woltering E. J. 2014. Quantifying lycopene synthesis and chlorophyll breakdown in tomato fruit using remittance VIS spectroscopy. Postharvest Biology and Technology, 96: 53-63 http://dx.doi.org/10.1016/j.postharvbio.2014.05.007

Siddiqui M. W. 2015. Postharvest biology and technology of horticultural crops - principles and practices for quality maintenance. USA, $572 \mathrm{p}$.

Sirisomboon P., Tanaka M., Kojima T. 2012. Evaluation of tomato textural mechanical properties. Journal of Food Engineering, 111 (4): 618-624 http://dx.doi.org/10.1016/j.jfoodeng.2012.03.007

Tiwari G., Slaugter D. C., Cantwell M. 2013. Nondestructive maturity determination in green tomatoes using a handheld visible and near infrared instrument. Postharvest Biology and Technology, 86: 221-229 http://dx.doi.org/10.1016/j.postharvbio.2013.07.009

Toivonen P. M. A., Brummell D. A. 2008. Biochemical bases of appearance and texture changes in fresh-cut fruit and vegetables. Postharvest Biology and Technology, 48: 1-14 http://dx.doi.org/10.1016/j.postharvbio.2007.09.004

Travers S., Bertelsen M. G., Kucheryavskij S. V. 2014. Predicting apple (cv. Elshof) postharvest dry matter and soluble solids content with near infrared spectroscopy. Journal of the Science of Food and Agriculture, 10 (1002): 955-962 http://dx.doi.org/10.1002/jsfa.6343

USDA Color Chart. 2011. <http://postharvest.ucdavis.edu/ pfvegetable/TomatoPhotos/?repository $=30014 \& \mathrm{a}=83755$ $>$ [accessed 1706 2015]

Zhu Q., He C., Lu R., Mendoza F., Cen H. 2015. Ripeness evaluation of 'Sun Bright' tomato using optical absorption and scattering properties. Postharvest Biology and Technology, 103: 27-34 http://dx.doi.org/10.1016/j.postharvbio.2015.02.007 
ISSN 1392-3196 / e-ISSN 2335-8947

Zemdirbyste-Agriculture, vol. 103, No. 1 (2016), p. 91-98

DOI $10.13080 /$ z-a.2016.103.012

\title{
Kokybinių rodiklių nustatymas nepažeidžiant pomidorų vaisiaus, taikant artimąją infraraudonają spektroskopiją
}

\author{
A. Radzevičius, J. Viškelis, R. Karklelienė, D. Juškevičienė, P. Viškelis
}

Lietuvos agrarinių ir miškų mokslų centro Sodininkystès ir daržininkystės institutas

\begin{abstract}
Santrauka
Tyrimų tikslas - nustatyti kokybinius pomidorų (veislè 'Rutuliai') rodiklius nepažeidžiant vaisiaus, taikant artimąą infraraudonają (AIR) spektroskopiją ir įprastinius metodus. Siekiant tiksliau įvertinti ryši tarp AIR spektroskopijos ir fizikinių bei cheminių analizių ir stebėti kokybės rodiklių pokyčius vaisių nokimo metu, bandymams buvo naudoti šešių skirtingų sunokimo lygių pomidorai. Pirmiausia buvo atlikti spektroskopiniai matavimai, po to vykdytos fizikinès ir cheminès analizès. AIR spektroskopijos ir ịprastinès analizès parodè, kad veikiant nokimo procesams pomidorų vaisiai prarado odelès bei minkštimo tvirtumą ir tarp taikytų metodų nustatant sausųjų medžiagų bei tirpių sausųų medžiagų kiekį nebuvo didelių skirtumų, o gauti rezultatai ịvairavo nedaug. Sausųjų medžiagų, tirpių sausųjų medžiagų kiekio ir vaisiaus minkštimo bei odelès tvirtumo duomenys apdoroti panaudojus paprastają tiesinę regresijos lygtị. Nustatyta stipri koreliacija tarp AIR spektroskopijos ir ịprastinès analizès metodų matuojant sausąsias medžiagas, kai regresijos koeficientas siekè 0,9089. Matuojant tirpias sausąsias medžiagas regresijos koeficientas tarp AIR spektroskopijos ir ịprastinès analizès buvo 0,815. Didžiausia koreliacija buvo nustatyta matuojant pomidorų minkštimo ir odelès tvirtumą - regresijos koeficiento reikšmè siekè atitinkamai 0,9119 ir 0,9624. Taigi, AIR spektroskopija sudaro galimybes įvertinti pomidorų vaisių fizikines ir chemines savybes atsižvelgiant i jų infraraudonųjų spindulių spektrą.
\end{abstract}

Reikšminiai žodžiai: artimoji infraraudonoji spektroskopija, sausosios medžiagos, sunokimas, tirpios sausosios medžiagos, tvirtumas.

Please use the following format when citing the article:

Radzevičius A., Viškelis J., Karklelienė R., Juškevičienė D., Viškelis P. 2016. Determination of tomato quality attributes using near infrared spectroscopy and reference analysis. Zemdirbyste-Agriculture, 103 (1): 91-98 DOI 10.13080/z-a.2016.103.012 